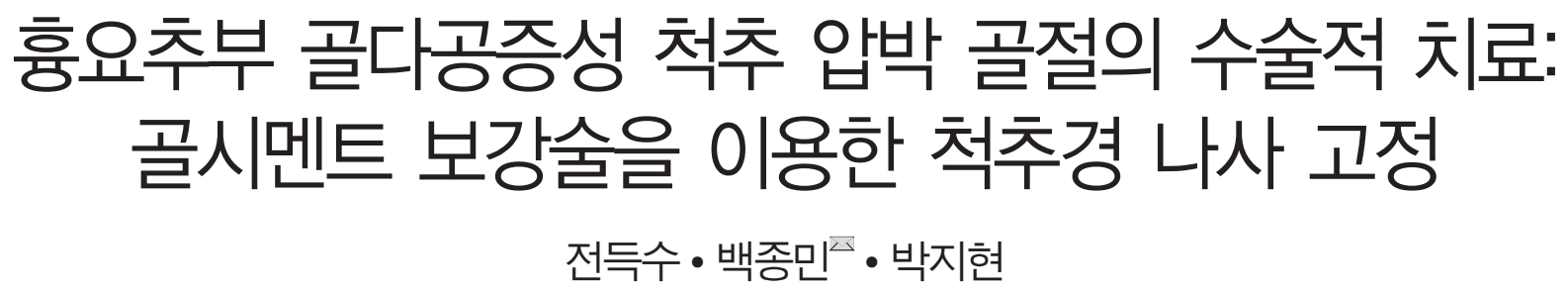

가천대 길병원 정형외과

\title{
Surgical Treatment of Osteoporotic Vertebral Compression Fractures at Thoraco-Lumbar Levels: Only Pedicle Screw Constructs with Polymethylmethacrylate Augmentation
}

\author{
Deuk Soo Jun, M.D., Ph.D., Jong-Min Baik, M.D. ${ }^{\square}$, and Ji Hyeon Park, M.D. \\ Department of Orthopedic Surgery, Gachon University Gil Medical Center, Incheon, Korea
}

\begin{abstract}
Purpose: To investigate the radiological efficacy of polymethylmethacrylate (PMMA) augmentation of pedicle screw operation in osteoporotic vertebral compression fractures (OVCF) patients.

Materials and Methods: Twenty OVCF patients, who underwent only posterior fusion using pedicle screws with PMMA augmentation, were included in the study. The mean follow-up period was 15.6 months. The demographic data, bone mineral density (BMD), fusion segments, number of pedicle screws, and amount of PMMA were reviewed as medical records. To analyze the radiological outcomes, the radiologic parameters were measured as the time serial follow-up (preoperation, immediately postoperation, postoperation 6 weeks, 3, 6 months, and 1 year follow-up).
\end{abstract}

Results: A total of 20 patients were examined (16 females [80.0\%]; mean age, $69.1 \pm 8.9$ years). The average BMD was $-2.5 \pm 0.9 \mathrm{~g} / \mathrm{cm}^{2}$. The average cement volume per vertebral body was $6.3 \mathrm{ml}$. The mean preoperative Cobb angle of focal kyphosis was $32.7^{\circ} \pm 7.0^{\circ}$ and was improved significantly to $8.7^{\circ} \pm 6.9^{\circ}$ postoperatively $(\mathrm{p}<0.001)$, with maintenance of the correction at the serial follow-up, postoperatively. The Cobb angle of instrumented kyphosis, wedge angle, and sagittal index showed similar patterns. In addition, the anterior part of fractured vertebral body height averaged $11.0 \pm 5.0 \mathrm{~mm}$ and was improved to $18.5 \pm 5.7 \mathrm{~mm}$ postoperatively $(\mathrm{p}=0.006)$, with maintenance of the improvement at the 3-month, 6-month, and 1-year follow-up.

Conclusion: The reinforcement of pedicle screws using PMMA augmentation may be a feasible surgical technique for OVCF. Moreover, it appears to be appropriate for improving the focal thoracolumbar/lumbar kyphosis and is maintained well after surgery.

Key words: osteoporosis, vertebral compression fracture, posterior pedicle screw fixation, polymethylmethacrylate augmentation

\footnotetext{
Received September 18, 2018 Revised October 24, 2018

Accepted November 12, 2018

Correspondence to: Jong-Min Baik, M.D.

Department of Orthopedic Surgery, Gachon University Gil Medical Center, 21

Namdong-daero 774beon-gil, Namdong-gu, Incheon 21565, Korea

TEL: +82-32-460-3384FAX: +82-32-460-3114 E-mail: bbaik@hanmail.net

ORCID: https://orcid.org/0000-0002-6646-2449
}

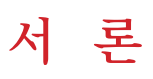

현대 고령화 사회에서 퇴행성 척추질환 및 골다공증은 주요한 의 학적 문제로 대두되고 있다. 특히 골다공증으로 인한 골절은 미 국과 유럽의 경우와 마찬가지로 한국에서도 주된 건강문제이자 경제적인 부담을 가중시키는 문제로 대두되고 있다. 또한 척추 의 압박 골절은 골다공증성 골절 중에 가장 흔한 골절로 미국에 서는 70만 건의 발생 빈도를 나타내었고, 한국에서도 동일하게 증 
Deuk Soo Jun, et al.

가하는 추세에 있다. ${ }^{1,2)}$ 골다공증성 척추 압박 골절은 골절 부위에 서 국소적인 후만을 야기시키며, 이 후만은 시상면 정렬의 불균 형을 야기시키고 요통으로 인해 삶의 질을 저하시킨다. 이를 해 결하기 위한 술식으로 Roy-Camille 등이 1963년에 척추경 나사 기구를 도입한 이래로 이는 척추질환을 다루는 데 가장 널리 사 용되는 기술이 되었다. ${ }^{3)}$ 이 기구의 장점은 강한 척추 고정력을 얻 을 수 있어 골이식편의 빠른 생착과 이에 따른 추체 유합을 얻을 수 있다는 점이지만 때때로 골다공증을 동반한 환자에서는 충분 한 초기 고정력을 얻을 수 없다는 단점이 있다. ${ }^{4,5)}$ 따라서 골다공 증성 척추 골절 환자에서 척추경 나사를 이용한 국소 후만의 교 정은 불량한 골질로 인해 어려울 수 있고, 교정 후에도 술 후 기 구 실패 및 고정력 상실의 위험성도 높다. 최근 사체의 척추를 이 용한 몇몇 실험실 연구에서 얻은 자료에 따르면 골시멘트 보강 술을 이용한 척추경 나사 고정은 축성 견인력 및 횡력에 대한 저 항성이 획기적으로 증가된 것으로 알려졌다. ${ }^{6-8)}$ 마찬가지로 골다 공증성 척추에서는 골시멘트의 일종인 폴리메칠메타크릴레이트 (polymethylmethacrylate, PMMA)의 사용이 골다공증성 골 내부 에 척추경 나사를 더욱 견고하게 고정시킨다고 알려져 있으며, 골다공증성 흥요추부 압박 골절과 연관된 방사선적 지표에 관한 몇몇 문헌들이 발표되었다. ${ }^{7-9)}$

본 연구에서는 골시멘트 보강술을 이용한 척추경 나사 고정이 국소적인 후만 변형을 호전시킬 수 있으며 골다공증성 척추 골절 환자에서 수술 후에도 잘 유지되게 한다고 가정하였다. 본 연구 의 목적은 골다공증성 척추 압박 골절 환자에서 척추경 나사못을 이용한 고정술을 시행 시 PMMA 골시멘트 보강의 방사선적 효용 성에 대해 조사하고자 하였다.

\section{대상 및 방법}

\section{1. 연구대상}

가천대 길병원 임상연구심의위원회의 허가(GCIRB No.: 2018325)를 받은 이후에 단일 기관에서 골다공증성 흥요추부 압박 골 절에 대해 골시멘트 보강술을 이용한 척추경 나사 고정을 시행 받은 모든 환자를 대상으로 후향적 연구를 수행하였으며 최소 추 시 기간은 1 년이었다. 연구 포함 기준은 다음과 같다: 1) Dual-energy X-ray absorptiometry를 이용한 골밀도 T 점수(bone mineral density [BMD], spine or hip T score) $<-1.0 \mathrm{~g} / \mathrm{cm}^{2}$; 2) 후만각 $>25^{\circ}$; 3) 추시 기간 최소 1 년.

추시기간이 1 년 미만인 환자, 추가적인 전방수술을 받았거나 재수술을 시행 받은 환자는 본 연구에서 제외되었다. 2014년 1월 부터 2016년 12월 사이의 기간 동안 흉요추부 골다공증성 압박 골 절에 대해 골시멘트 보강술을 이용한 후방 척추경 나사 고정술 을 시행받은 20 예의 환자가 연구에 포함되었다. 나이, 성별 등을 포함한 자료와 골밀도, 골절된 추체 부위, 유합 분절, 시멘트를 주 입한 추체, 주입된 시멘트의 양, 추시 기간 등의 연구 자료는 전자 의무 기록을 통해 후향적으로 수집되었다.

\section{2. 방사선적 지표의 측정}

방사선적 자료는 의료영상 저장전송시스템(picture archiving and communication system)을 이용하여 측정하였다. 척추 변형을 계 산하기 위해 후만각, 설상각, 시상지표(sagittal index, SI), 기구 교 정각, 측면 방사선 상에서의 골절 추체 전방 높이를 측정하였다. 각 측정값은 $150 \%$ 확대된 비율의 단순 방사선 사진을 통해 일괄
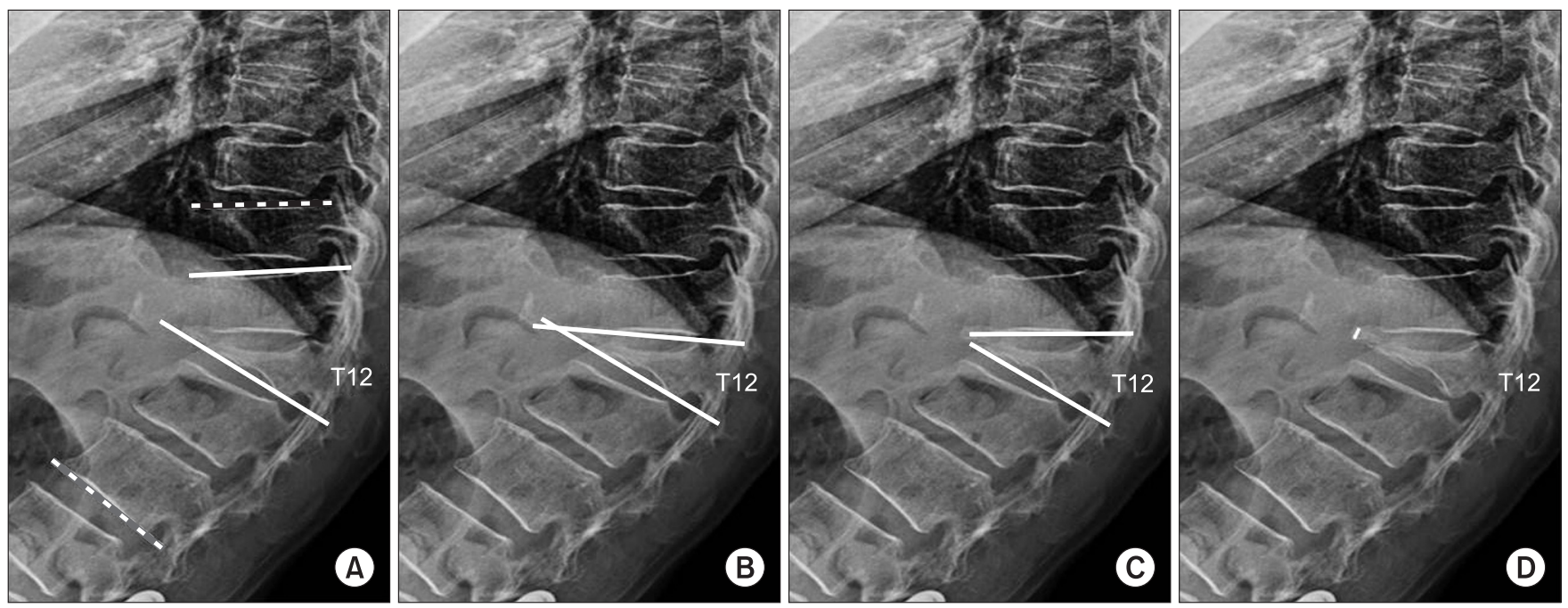

Figure 1. Evaluation of the radiographic parameters. (A) Kyphosis angle (dotted lines): Most kyphotic Cobb's angle including fractured vertebra $\left(^{\circ}\right)$, instrumented angle (solid lines): Cobb's angle of instrumented vertebra $\left(^{\circ}\right)$. (B) Wedge angle: Angle of fractured vertebra between upper and lower endplate $\left(^{\circ}\right)$. (C) Sagittal index: Sagittal index of fractured vertebra $\left(^{\circ}\right)$. (D) Anterior fractured vertebra body height $(\mathrm{mm})$. 
적으로 측정하였다. 후만각은 콥스각 측정법을 이용하여 골절 부 위를 포함하여 측정하고, 가장 큰 각도를 사용하였으며 설상각은 골절된 추체의 상부 종판과 하부 종판이 이루는 각도를 측정하였 다. SI는 골절 부위의 분절 변형을 추정하는 데 도움을 주는 지표 로서 변형된 분절에서 후만 분절 변형이 변형이 정상 시상면 윤 곽으로 교정되는 데 필요한 정도를 측정하게 된다. 본 연구에서 는 흥추부에서는 각 운동 분절당 $5^{\circ}$ 의 후만각을 제 12 흥추는 중립 으로 하였으며, 제1요추 이하로는 분절당 $10^{\circ}$ 의 전만으로 계산하 여 측정된 후만각을 보정하였다. 기구 교정각은 콥스각 측정법을 이용하여 기구가 삽입된 최상부 추체의 상부 종판에 평행한 선과 기구가 삽입된 최하부 추체의 하부 종판에 평행한 선이 이루는 각도를 측정하였다. 골절 추체 전방높이는 골절된 추체의 전방부 높이를 측정하였다(Fig. 1). 수술 후 추시 기간 동안 나사의 이완, 뽑힘, 파손이나 인접 분절의 골절과 같은 합병증에 대해서는 순 차적 단순 방사선 사진을 통해 확인하였다.

\section{3. 수술기법}

모든 환자는 모두 후방 접근법을 사용하여 PMMA 골시멘트 (Surgical Simplex P; Howmedica International S. de RL, Limerick, Ireland) 보강술을 이용한 척추경 나사 고정술을 시행하였으며 골시멘트 주입을 통한 보강은 단일 술자(D.S.J)에 의해 시행되었 다. 환자는 C-arm 방사선 투과가 가능한 테이블(Jackson Spinal Table System; Mizuno OSI, Union City, CA, USA) 위에 복와위로 양 고관절과 슬관절은 $20^{\circ}$ 굴곡된 상태로 위치되었다. 후방 접근 법을 통해 척추에 접근한 후에 C-arm 방사선 기기는 후-전 및 측 면 방사선 촬영을 위해 위치시켰으며 골시멘트 보강술 시행 시에 는 척추경 나사의 위치를 확인하기 위해 술 중 C-arm 방사선 기 기 촬영을 이용하였다. 척추경 나사 삽입 경로의 확인은 탐침을 이용하여 척추경의 내벽 및 추체의 전면부 벽이 손상되지 않았음 을 촉지하여 확인하였고, 척추경 나사 삽입 경로에 추체 성형술 에 사용되는 골시멘트 충진 바늘(Jamshidi ${ }^{\circledR}$; BD, Franklin Lakes, $\mathrm{NJ}, \mathrm{USA})$ 을 위치시켰다. C-arm 방사선 기기를 통해 바늘의 위치 를 확인한 후에 PMMA 골시멘트를 척추경 나사 경로를 통해 주

Table 1. Demographics of All Patients

\begin{tabular}{|c|c|c|c|c|c|c|c|c|c|}
\hline $\begin{array}{l}\text { Patient } \\
\text { No. }\end{array}$ & $\begin{array}{l}\text { Age } \\
(y r)\end{array}$ & Sex & $\begin{array}{l}\mathrm{BMD} \\
\left(\mathrm{g} / \mathrm{cm}^{2}\right)\end{array}$ & $\begin{array}{l}\text { Follow-up } \\
\text { period (mo) }\end{array}$ & $\begin{array}{l}\text { Fracture } \\
\text { site }\end{array}$ & Fusion level & $\begin{array}{c}\text { Cemented } \\
\text { vertebra }\end{array}$ & $\begin{array}{c}\text { Cement } \\
\text { volume (ml) }\end{array}$ & $\begin{array}{c}\text { Average } \\
\text { cement volume } \\
1 \text { vertebra (ml) }\end{array}$ \\
\hline 1 & 73 & $\mathrm{~F}$ & -3.3 & 24 & L2 & L1-3 & L1, L3 & 14.5 & 7.3 \\
\hline 2 & 53 & M & -1.9 & 30 & $\mathrm{~T} 12$ & T11-L1 & T11, L1 & 15.4 & 7.7 \\
\hline 3 & 72 & $\mathrm{~F}$ & -1.6 & 17 & L1 & T11-L3 & T11, T12, L2, L3 & 24.5 & 6.1 \\
\hline 4 & 59 & $\mathrm{~F}$ & -1.5 & 24 & $\mathrm{~T} 12$ & T10-L1 & T12, L1 & 12.4 & 6.2 \\
\hline 5 & 77 & $\mathrm{~F}$ & -3.5 & 12 & $\mathrm{~T} 12$ & T11-L1 & T11, L1 & 13.1 & 6.6 \\
\hline 6 & 72 & F & -3.6 & 20 & $\mathrm{~T} 11$ & T10-12 & $\mathrm{T} 10, \mathrm{~T} 11, \mathrm{~T} 12$ & 18.9 & 6.3 \\
\hline 7 & 70 & $\mathrm{~F}$ & -2.5 & 13 & L2 & T12-L3 & T12, L3 & 13.4 & 6.7 \\
\hline 8 & 69 & $\mathrm{~F}$ & -3.6 & 13 & $\mathrm{~T} 12$ & T10-L2 & T11, L1 & 13.5 & 6.8 \\
\hline 9 & 55 & $\mathrm{~F}$ & -2.9 & 12 & L1 & T12-L2 & T12, L2 & 12.6 & 6.3 \\
\hline 10 & 59 & M & -1.2 & 12 & T9 & T8-11 & $\mathrm{T} 11$ & 6.2 & 6.2 \\
\hline 11 & 58 & M & -2.8 & 12 & $\mathrm{~T} 12$ & T11-L1 & T11, L1 & 12.8 & 6.4 \\
\hline 12 & 59 & $\mathrm{~F}$ & -4 & 17 & L2 & L1-3 & L1, L3 & 12.4 & 6.0 \\
\hline 13 & 74 & $\mathrm{~F}$ & -1.8 & 12 & $\mathrm{~T} 12$ & T10-L2 & T10, T11, L1, L2 & 24.1 & 6.4 \\
\hline 14 & 71 & $\mathrm{~F}$ & -1.3 & 22 & L1 & T12-L2 & T12, L1, L2 & 19.2 & 6.1 \\
\hline 15 & 78 & $\mathrm{~F}$ & -1.9 & 12 & $\mathrm{~T} 12$ & T11-L1 & T11, T12, L1 & 18.3 & 5.0 \\
\hline 16 & 77 & $\mathrm{~F}$ & -2.5 & 12 & T9 & $\mathrm{T} 7-10$ & $\mathrm{~T} 7, \mathrm{~T} 10$ & 9.9 & 4.5 \\
\hline 17 & 83 & $\mathrm{~F}$ & -3 & 12 & L1 & T12-L2 & T12, L1, L2 & 18.6 & 6.2 \\
\hline 18 & 75 & $\mathrm{~F}$ & -2.9 & 12 & L1 & T12-L2 & T12, L2 & 12.6 & 6.3 \\
\hline 19 & 67 & $\mathrm{~F}$ & -2.1 & 12 & L1 & T12-L2 & T12, L2 & 12.4 & 6.2 \\
\hline 20 & 80 & M & -1.9 & 12 & L3 & L2-4 & L2, L4 & 12.2 & 6.1 \\
\hline Average & 69.1 & & -2.5 & 15.6 & & Total 70 levels & Total 47 vertebra & Total 297 & 6.3 \\
\hline
\end{tabular}

$\mathrm{BMD}$, bone mineral density; F, female; $\mathrm{M}$, male 
Deuk Soo Jun, et al.

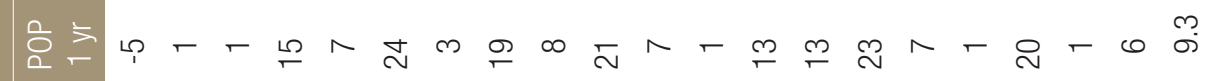

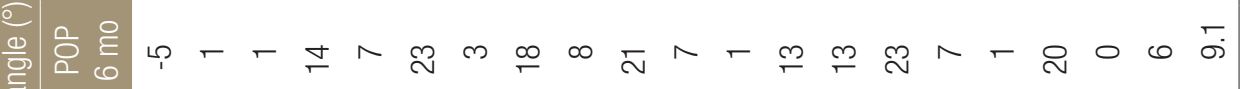

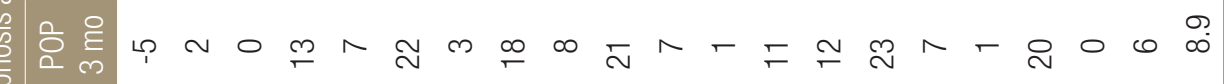

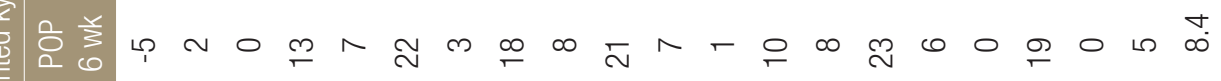

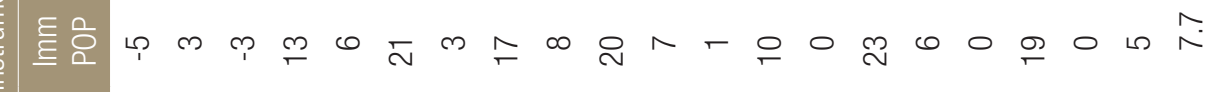
은

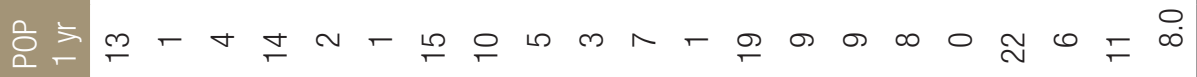
응 임

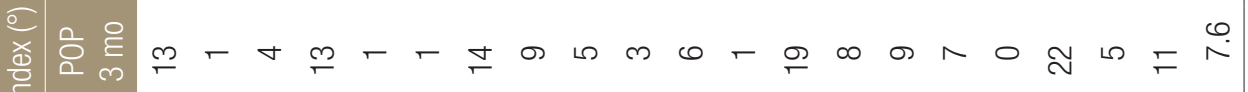
带旁旁 車立

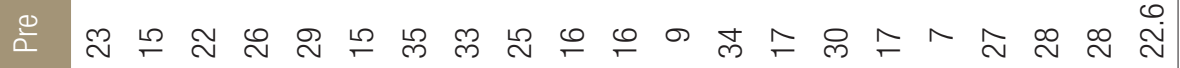

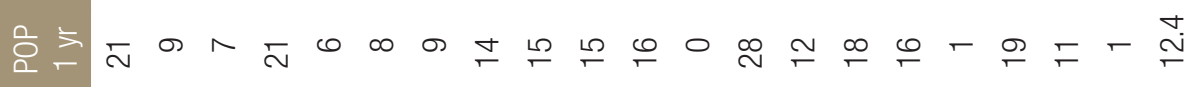
응

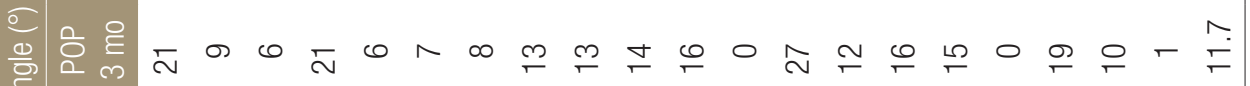
尊

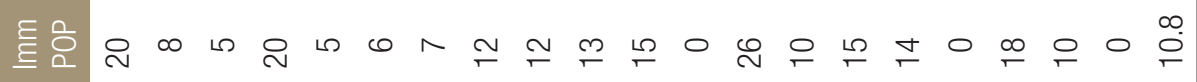

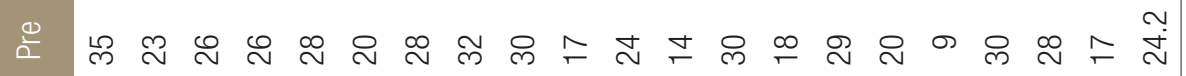
은

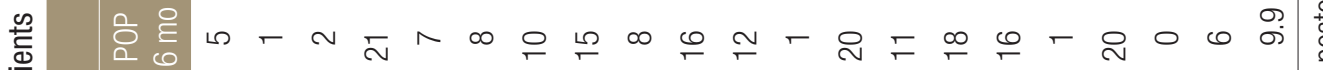

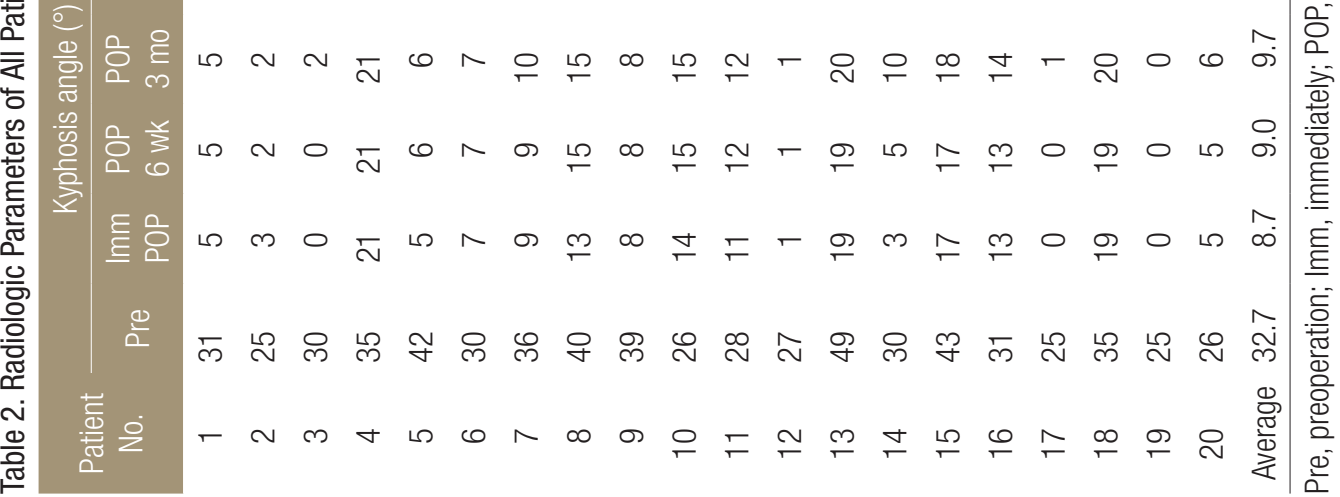


입하였다. 골시멘트가 수술용 장갑에 달라 붙지 않을 정도의 점 도가 되었을 때 즉시 추체의 전면벽을 침범하지 않는 한도 내에 서 척추경 나사 본래의 길이만큼 척추경 나사를 삽입하였다. 모 든 환자에 대해서 후방 감압술은 시행하지 않았으며, 골유합술은 후방 유합술을 시행하였다. 후방 유합술 시 골이식재는 동종골 (allobone, MegaBone ${ }^{\circledR}$; L\&C Bio, Seongnam, Korea)을 이용하였다.

\section{4. 통계적 분석}

연구 자료의 분류 및 통계적 분석은 PASW ver. 18.0 통계 프로그 램(IBM Corp., Armonk, NY, USA)을 이용하였다. 두 시점의 추시 기간 이상에서 측정된 변수에 대한 분석은 종단 분석을 사용하여 각각의 환자의 자료를 KruskKall-Wallies 검사법을 통하여 분석 하였다. 0.05 미만의 p-value에서 통계적으로 유의성이 있다고 판 단하였다.

\section{결 과}

총 20예의 환자가 본 연구에 포함되었다(여자 16예[80.0\%]; 평 균 나이, 69.1 \pm 8.9 세; 평균 추시 기간, $15.6 \pm 7.7$ 개월). 평균 $\mathrm{BMD}$ 는 $-2.5 \pm 0.9 \mathrm{~g} / \mathrm{cm}^{2}$ 로 나타났다. 총 유합 분절은 70 분절이었으며, PMMA 골시멘트를 주입한 추체는 총 47개였고, 각 추체에 주입 된 골시멘트의 평균양은 $6.3 \mathrm{ml}$ 였다(Table 1).

수술 전 후만각은 평균 $32.7^{\circ} \pm 7.0^{\circ}$ 였으며, 수술 후 $8.7^{\circ} \pm 6.9^{\circ}$ 로 교정되었고 $(p<0.001)$, 수술 후 3 개월, 6 개월, 1 년에 측정한 후만 각은 각각 $9.7^{\circ} \pm 6.9^{\circ}, 9.9^{\circ} \pm 7.1^{\circ}, 10.1^{\circ} \pm 7.0^{\circ}$ 로 유지되었다. 설상각 은 수술 전 평균 $24.2^{\circ} \pm 6.8^{\circ}$ 에서 수술 후 $10.8^{\circ} \pm 7.1^{\circ}$ 로 호전되었으 며 $(\mathrm{p}<0.001)$, 수술 후 3 개월, 6 개월, 1 년에 측정한 설상각은 각각 $11.7^{\circ} \pm 7.3^{\circ}, 12.1^{\circ} \pm 7.4^{\circ}, 12.4^{\circ} \pm 7.4^{\circ}$ 로 측정되었다. SI는 수술 전 평 균 $22.6^{\circ} \pm 8.2^{\circ}$ 에서 수술 후 $7.0^{\circ} \pm 6.3^{\circ}$ 로 교정되었고 $(\mathrm{p}<0.001)$, 수 술 후 3 개월, 6 개월, 1 년에 측정한 SI는 각각 $7.6^{\circ} \pm 6.2^{\circ}, 8.0^{\circ} \pm 6.3^{\circ}$, $8.0^{\circ} \pm 6.3^{\circ}$ 로 나타났다. 기구 삽입 후만각은 수술 전 평균 $27.8^{\circ} \pm$ $12.1^{\circ}$ 에서 수술 후 $7.7^{\circ} \pm 8.5^{\circ}$ 로 호전되었으며 $(\mathrm{p}<0.001)$, 수술 후

Table 3. Radiologic Parameters; Vertebral Body Height (Anterior Part) (mm)

\begin{tabular}{ccccccc} 
& \multicolumn{5}{c}{ Vertebral body height $(\mathrm{mm})$} \\
\hline 1 & Pre & Imm POP & POP 6 wk & POP 3 mo & POP 6 mo & POP 1 yr \\
2 & 11.6 & 15.5 & 12.6 & 13.1 & 13 & 12.8 \\
3 & 15 & 27 & 23 & 27 & 27.5 & 27.5 \\
4 & 6 & 18.2 & 17.1 & 16.3 & 16.8 & 16.7 \\
5 & 8.7 & 13.1 & 13.5 & 13.4 & 13.5 & 13.1 \\
6 & 9.9 & 18.7 & 17.9 & 18 & 18 & 18 \\
7 & 17.4 & 23.8 & 20.9 & 20.1 & 19.8 & 19.7 \\
8 & 8.1 & 14 & 14.6 & 14.8 & 14.5 & 14.6 \\
9 & 3.6 & 17.4 & 15.6 & 15.2 & 14.1 & 13.8 \\
10 & 8.9 & 22.3 & 19.3 & 18.1 & 18.3 & 18 \\
11 & 13.7 & 16.6 & 13.8 & 13.7 & 13.7 & 13.7 \\
12 & 16 & 18.8 & 19 & 18.8 & 18.6 & 18.5 \\
13 & 17.5 & 23.7 & 23.1 & 23 & 23 & 23 \\
14 & 4.2 & 8.2 & 8.1 & 7.9 & 8 & 8 \\
15 & 12.3 & 19.3 & 18.8 & 17.4 & 17.2 & 17.2 \\
16 & 2.3 & 14 & 13.8 & 12 & 12 & 12 \\
17 & 8.4 & 8.9 & 8.2 & 7 & 7 & 7 \\
18 & 19.6 & 27.3 & 27.1 & 27 & 27 & 27 \\
19 & 7.7 & 12.5 & 12.3 & 12.3 & 11.9 & 11.8 \\
20 & 13.3 & 23.8 & 23.5 & 23.4 & 23.4 & 23.3 \\
Average & 15.2 & 25.8 & 25.6 & 25.6 & 25.3 & 25.3 \\
\hline
\end{tabular}

Pre, preoperation; Imm, immediately; POP, postoperation. 
Deuk Soo Jun, et al.

3 개월, 6 개월, 1 년에 측정한 기구 삽입 후만각은 $8.9^{\circ} \pm 8.4^{\circ}, 9.1^{\circ}$ $\pm 8.5^{\circ}, 9.3^{\circ} \pm 8.7^{\circ}$ 로 측정되었다. 골절 추체 전방 높이는 수술 전 평균 $11.0 \pm 5.0 \mathrm{~mm}$ 에서 수술 후 $18.5 \pm 5.7 \mathrm{~mm}$ 로 증가되었으며 ( $\mathrm{p}=0.006)$ 수술 후 3 개월, 6 개월, 1 년에 측정한 골절 추체 전방 높 이는 $17.2 \pm 5.8 \mathrm{~mm}, 17.1 \pm 5.9 \mathrm{~mm}, 17.1 \pm 5.9 \mathrm{~mm}$ 로 확인되었다 (Table 2, 3, Fig. 2).

본 연구의 수술 후 추시 기간 동안 나사의 이완, 뽑힘, 파손이나 인접 분절의 골절은 관찰되지 않았다. 아래 본 연구의 증례를 나 타내었다(Fig. 3).

\section{고 찰}

척추 수술 중에서도 골다공증성 척추 골절의 수술적 치료는 어려 운 분야 중 하나라고 할 수 있다. 그 이유는 환자군 자체가 고령이 며 다른 내과적 질환을 동반하고 있을 가능성이 높고 따라서 수

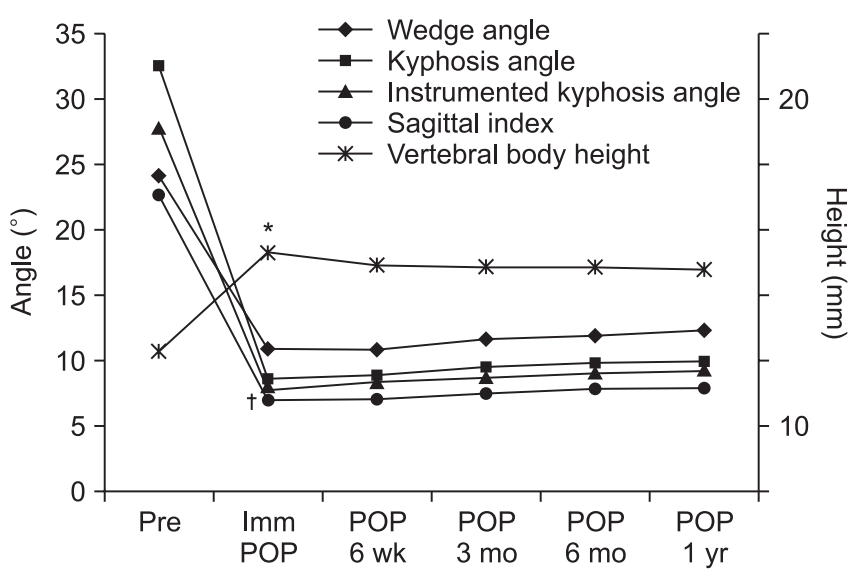

Figure 2. Results of the radiologic parameters. Values related to the radiologic angle show the same trend $\left({ }^{*} p=0.006 ;{ }^{\dagger} p<0.001\right)$. Pre, preoperation; Imm, immediately; POP, postoperation.
술의 위험도 또한 높기 때문이다. 뿐만 아니라 골다공증으로 인 한 불량한 골질로 내 고정 기구를 통해 만족할 만한 강한 고정력 을 얻기 어렵고, 구조성 이식편의 삽입은 골다공증성 척추의 침 강을 수반할 수 있으며 이에 따른 불유합 및 변형의 재발이 흔하 기 때문이다. 또한 골다공증성 척추의 해면골에서는 특징적으로 골소주 간의 거리가 늘어나 있고, 이는 나사못을 붙잡는 힘과 골금속간 접촉 면적이 감소되어 있다. 이는 곧 나사못 주변 전체 부 위의 골용해 및 금속 삽입물의 해리를 유발하게 되며, 결과적으 로 흔히 뽑힘(pull-out) 현상의 결과가 초래된다. 따라서 성공적인 수술의 결과를 얻기 위해서는 수술적 치료에 적절한 환자를 선정 하고 환자 개개인에 맞게 차별화된 치료전략을 세우는 것이 매우 중요하다. 아직 수술적 치료의 적응증에 대해 명확하게 확립되어 있지는 않으나 심한 후만 변형으로 인한 통증이 있는 경우나 후 방 골절편의 압박으로 인한 척수 마비 증세가 있을 때, 골절된 추 체의 골괴사나 불유합으로 인한 불안정성이 야기된 경우와 같이 특수한 경우에는 수술적 치료를 고려하여야 한다.

후방 척추경 나사못 고정술은 골다공증성 척추 골절을 안정 화시키는 데 가장 널리 사용되는 수술법이며 척추의 전방 부위 가 불안정성 없이 온전한 편이라면 후방 고정만으로도 충분할 수 도 있다. 하지만 후방 고정술을 골다공증성 추체에 시행하게 되 면 토글링(toggling) 현상으로 인해 나사의 해리와 뽑힘으로 인한 나사 실패가 나사의 파손보다 흔하게 발생한다. 달리 말하면 골 다공증 환자에서는 골-나사 접촉 면적 확보에 실패하게 되고, 이 는 척추경 나사의 해리와 뽑힘 또는 종판을 뜷고 인접 추체의 추 간판이나 추체를 침범하는 결과를 초래할 수 있음을 의미한다. 이러한 맥락에서 골다공증 환자의 수술 시 뽑힘 현상을 예방하는 것이 매우 중요하다고 할 수 있으며 척추경 나사의 뽑힘 저항 강 도(pull-out strength)를 높이기 위해 PMMA 골시멘트 보강술을 시행하는 것은 매우 유용한 술식일 수 있겠다.

본 연구는 후방 도달법으로 골시멘트 보강술을 이용한 후방 척
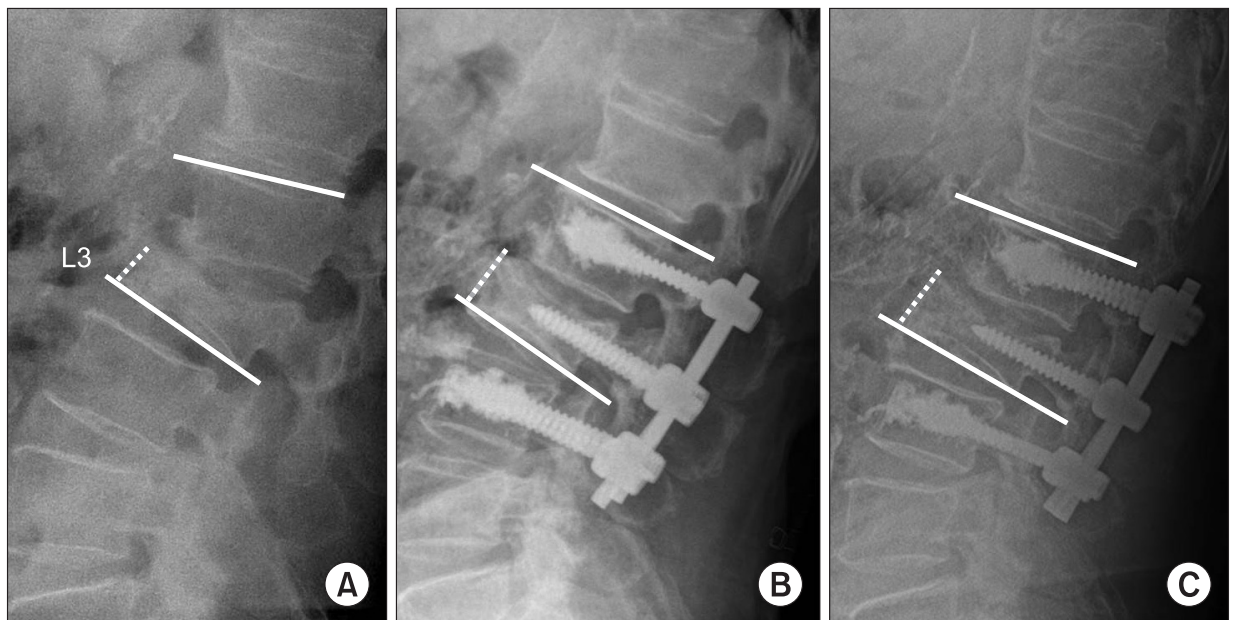

Figure 3. Case number 20; the patient was male and 80 years old. He was diagnosed with a compression fracture L3 by low-energy trauma and a spine $T$ score -1.9 on dual-energy X-ray absorptiometry. (A) The kyphosis angle (solid lines) of $L 3$ was measured to be $26^{\circ}$ and anterior body height (dotted line) was observed to $15.2 \mathrm{~mm}$, preoperatively. (B) Immediately after surgery, these values were measured to be $5^{\circ}$ and $25.8 \mathrm{~mm}$, respectively. (C) Kyphosis angle, $6^{\circ}$; anterior body height, $25.3 \mathrm{~mm}$ at 1 year, postoperatively. 
추경 나사못 고정술을 시행한 환자에 대한 방사선적 지표를 조 사하였다. 그리고 그 결과는 수술 후 통계적으로 유의하게 교정 되었으며, 추시 기간 동안에 잘 보존되는 결과를 나타내었다. 하 지만 골다공증성 척추 골절 환자에게서 척추 후만과 동시에 신 경 증상이 있는 경우나 신경 감압의 필요성이 있는 경우에는 전 방 도달법을 통한 감압술 및 전방 재건술을 시행해 주어야 할 것 이다. 그러나 본 연구에서는 신경 증상이 없는 환자에게서 골다 공증성 압박 골절 부위에 상기 술기를 시행하였으며, 만족할 만 한 결과를 나타내었다. 여러 문헌에서도 골시멘트의 최대 효율성 을 얻기 위한 연구 결과가 있었는데, Cohen 등 ${ }^{10}$ 에 의하면 골다공 증성 추체의 뽑힘 저항 강도에 대해 $1,2,3 \mathrm{ml}$ 로 각각 다른 양의 PMMA 골시멘트를 주입하여 보강술을 시행하였을 때 뽑힘 저항 강도는 각각 $75 \%, 500 \%, 700 \%$ 로 증가되었다고 발표하였다. ${ }^{11,12}$

본 연구도 각 척추 경(pedicle)당 $3 \mathrm{ml}$ 이상의 골시멘트를 주입 하는 것을 목표로 하여 최대의 저항 강도를 얻으려고 하였다. 이 외에도 성공적인 수술 결과를 도출하기 위해 다음과 같은 추가적 인 요인들에 대해 주의 깊게 생각해 보아야 할 것이다. 첫째, 골시 멘트를 주입 후 나사를 삽입하는 가장 적절한 시기는 시멘트의 굳기 정도가 doughy state로 알려져 있으며, 이 때 나사 삽입 시 최 대의 뽑힘 강도를 얻을 수 있다. 하지만 나사 삽입 시기를 놓쳐 시 멘트가 너무 굳어진 상태에서 삽입하게 되면 골시멘트에 금이 가 면서 나사못이 잘못된 위치에 삽입되거나 삽입 강도가 약화될 수 있으므로 주의를 요한다. 두 번째로, 나사못의 삽입 비틀림 모멘 트(Touque)와 나사못의 안정성, 즉 골접촉 면적을 증가시키기 위 해 가능하면 척추경 나사못의 길이와 직경을 큰 것을 사용해야 한다. 세 번째로, 뽑힘 저항 강도를 증가시키기 위해서는 나사못 의 삽입 궤적을 내측으로 수렴하는 방향(convergence)으로 하고 나사를 삽입해야 할 것이다. 네 번째로, 연조직과 골유착을 충분 히 제거하여 나사를 다룰 때 강봉(rod)에 가해지는 부하가 최소화 되도록 하여야 한다. 마지막으로 수술 후에도 충분한 기간 동안 흥요천추 보조기(thoracic-lumbar-sacral orthosis)를 착용시키고 부갑상선호르몬(parathyroid hormone) 등의 골형성 제제 사용을 고려해야 한다.

본 연구의 한계점은 후향적 연구이며 연구 대상의 크기가 작 고 추시기간이 짧은 데 있다. 그리고 본 술기를 시행한 초기에는 척추경 나사의 뽑힘을 방지하기 위해 골시멘트 보강술을 시행 한 위, 아래 분절에 척추경 나사 삽입술을 시행하였으나 후기에 는 결과의 호전을 고려하여 골시멘트 보강술을 골절 부위 위, 아 래에만 시행하여 수술을 시행하였다. 이는 일정한 분절의 고정을 고려하지 않아 결과적 편견(bias)을 유발할 수 있다고 생각된다. 또한 visual analogue scale이나 Oswestry disability index 같은 임상 적 자료는 평가하지 않았으며 대조군과의 비교는 고려되지 않았 다는 점이다.

\section{결 론}

변형을 동반한 골다공증성 척추 골절의 수술적 치료는 여전히 어 렵고 많은 합병증을 동반할 수 있다. 특히 수술 후의 고정 실패는 나사의 해리나 뽑힘으로 인해 발생한다고 보여진다. 따라서 골다 공증성 압박 골절에서 골시멘트 보강술을 이용한 척추경 나사 고 정은 효과적인 치료법이라 생각되며, 이 술식을 통해 국소 흥요 추부 후만의 충분한 교정을 얻을 수 있고 술 후에도 잘 유지할 수 있는 방법으로 골다공증 척추 압박 골절 환자에서 유용한 술식으 로 생각된다.

\section{CONFLICTS OF INTEREST}

The authors have nothing to disclose.

\section{REFERENCES}

1. Melton LJ 3rd. Epidemiology of spinal osteoporosis. Spine (Phila Pa 1976). 1997;22:2S-11S.

2. Rowe SM, Yoon TR, Ryang DH. An epidemiological study of hip fracture in Honam, Korea. Int Orthop. 1993;17:139-43.

3. Roy-Camille R, Saillant G, Mazel C. Internal fixation of the lumbar spine with pedicle screw plating. Clin Orthop Relat Res. 1986;203:7-17.

4. Shikata J, Yamamuro T, Iida H, Shimizu K, Yoshikawa J. Surgical treatment for paraplegia resulting from vertebral fractures in senile osteoporosis. Spine (Phila Pa 1976). 1990;15:485-9.

5. Baba H, Maezawa Y, Kamitani K, Furusawa N, Imura S, Tomita K. Osteoporotic vertebral collapse with late neurological complications. Paraplegia. 1995;33:281-9.

6. Sarzier JS, Evans AJ, Cahill DW. Increased pedicle screw pullout strength with vertebroplasty augmentation in osteoporotic spines. J Neurosurg. 2002;96:S309-12.

7. Soshi S, Shiba R, Kondo H, Murota K. An experimental study on transpedicular screw fixation in relation to osteoporosis of the lumbar spine. Spine (Phila Pa 1976). 1991;16:1335-41.

8. Wittenberg RH, Lee KS, Shea M, White AA 3rd, Hayes WC. Effect of screw diameter, insertion technique, and bone cement augmentation of pedicular screw fixation strength. Clin Orthop Relat Res. 1993;296:278-87.

9. Cook SD, Salkeld SL, Stanley T, Faciane A, Miller SD. Biomechanical study of pedicle screw fixation in severely osteopo- 
Deuk Soo Jun, et al.

rotic bone. Spine J. 2004;4:402-8.

10. Cohen D, Cullinane D, Iizuka M, Walk N, Kostuik J. Biomechanics of pedicle screw augmentation using polymethylmethacrylate. New Orleans: North American Spine Society; 2000.

11. Halvorson TL, Kelley LA, Thomas KA, Whitecloud TS 3rd,
Cook SD. Effects of bone mineral density on pedicle screw fixation. Spine (Phila Pa 1976). 1994;19:2415-20.

12. McLain RF, McKinley TO, Yerby SA, Smith TS, Sarigul-Klijn $\mathrm{N}$. The effect of bone quality on pedicle screw loading in axial instability. A synthetic model. Spine (Phila Pa 1976). 1997;22:1454-60. 


\section{흉요추부 골다공증성 척추 압박 골절의 수술적 치료: 골시멘트 보강술을 이용한 척추경 나사 고정 \\ 전득수・백종민 • 박지현}

가천대 길병원 정형외과

목적: 골다공증성 척추 압박 골절 환자에서 척추경 나사못을 이용한 고정술을 시행 시 골시멘트(polymethylmethacrylate) 보강의 방 사선적 효용성에 대해 조사하고자 하였다.

대상 및 방법: 골다공증성 압박 골절에서 골시멘트 보강술을 이용한 척추경 나사 고정을 시행한 20예의 환자가 연구에 포함되었다. 평균 추시 기간은 15.6 개월이었으며, 인구학적인 자료, 골밀도(bone mineral density, $\mathrm{BMD}$ ), 유합 분절, 척추경 나사의 사용 개수 및 골시멘트 주입량은 의무기록을 통하여 검토되었다. 방사선적인 결과를 산출하기 위하여 시간 순차적(수술 전, 수술 직후, 술 후 6주, 술 후 3,6 개월 및 술 후 1년) 추시를 통해 방사선적 지표를 측정하였다.

결과: 본 연구에 총 20명의 환자(여자 16예[80.0\%]; 평균 나이, $69.1 \pm 8.9$ 세)가 포함되었다. 평균 $\mathrm{BMD}$ 는 $-2.5 \pm 0.9 \mathrm{~g} / \mathrm{cm}^{2}$, 각각 의 추체당 평균 골시멘트 주입량은 $6.3 \mathrm{ml}$ 였다. 술 전 측정한 후만각(Cobb angle)은 $32.7^{\circ} \pm 7.0^{\circ}$ 였으며, 술 후 측정값은 $8.7^{\circ} \pm$ $6.9^{\circ}$ ( $\mathrm{p}<0.001$ )로 큰 호전을 나타내었고, 교정은 술 후 시간 순차적인 추시에서도 유지됨을 보였다. 기구 고정 후 후만각, 설상각, 시상지표 또한 유사한 호전 양상을 나타내었다. 또한 골절된 추체의 전방 높이 또한 수술 전 $11.0 \pm 5.0 \mathrm{~mm}$ 에서 수술 후 $18.5 \pm 5.7$ $\mathrm{mm}(\mathrm{p}=0.006)$ 로 호전되었고 3,6 개월 및 1년간의 추시 간에도 유지됨이 확인되었다.

결론: 골다공증성 압박 골절에서 골시멘트 보강술을 이용한 척추경 나사 고정은 효과적인 치료법이라 생각되며, 이 술식을 통해 국 소 흉요추부 후만의 충분한 교정을 얻을 수 있고 술 후에도 잘 유지할 수 있는 방법으로 골다공증 척추 압박 골절 환자에서 유용한 술 식으로 생각된다.

색인단어: 골다공증, 척추 압박 골절, 후방 척추경 나사 고정술, 폴리메칠메타크릴레이트 보강술

접수일 2018년 9월 18일 수정일 2018년 10월 24일 게재확정일 2018년 11월 12일

책임저자 백종민

21565 , 인천시 남동구 남동대로 774 번길 21 , 가천대 길병원 정형외과

TEL 032-460-3384, FAX 032-460-3114, E-mail bbaik@hanmail.net, ORCID https://orcid.org/0000-0002-6646-2449 